\title{
RATIONAL CHOICE OF MACHINING TOOLS USING PREDICTION PROCEDURES
}

\author{
Oleg Krol \\ Department of Machinery Engineering and Applied Mechanics \\ Volodymyr Dahl East Ukrainian National University \\ 59-a Tsentralnyi ave., Severodonetsk, Ukraine, 93400 \\ krolos.snu.edu@gmail.com \\ Volodymyr Sokolov \\ Department of Machinery Engineering and Applied Mechanics \\ Volodymyr Dahl East Ukrainian National University \\ 59-a Tsentralnyi ave., Severodonetsk, Ukraine, 93400 \\ sokolov.snu.edu@gmail.com
}

\begin{abstract}
Introducing the methods and procedures for predictive analysis into the design process contours of a variety of machining tools (MT) of metal cutting machines is the main aim of this article. A sequence of realization of prediction object (PO) choice as an initial stage of search of perspective designs is offered. Effective in this regard is the "Tree of objectives" apparatus, on the basis of which many ways of improving MT are formed, selecting progressive (reducing the dimension of the problem) at each level of the hierarchy of the constructed graph-tree. The procedure for selecting the prediction method (PM) as a means of generating the forecast data is developed. The task of choosing a method is structured in detail and uses "Information supply"as the main criterion. To this end, assessment scales of choice criteria have been formed, on the basis of which it is possible to evaluate their effectiveness for the PM selection process. The rules for PO coding are introduced by a three-element information code, including information source classes - static data, expert estimates and patent data. The process of forecasting the MT components by the method of engineering forecasting on the basis of a representative patent fund is realized. The General Definition Table has been built (GDT "Machining tools") and estimates of the prospects of design solutions have been obtained. A fragment of the database of 3D models of promising MT designs in the integrated computer-aided design KOMPAS-3D is proposed.
\end{abstract}

Keywords: machining tools, metal cutting machine, prediction procedure, choice of prediction method, patent search, 3D model.

\section{Introduction}

In the process of making design decisions, the machine tool builder faces the problem of identifying and using the most avant-garde technical solutions. The main areas of improvement in the machine tool industry include: increasing the processing capacity, improving the accuracy of manufacturing and expanding the technological capabilities of modern equipment. In accordance with the basic principle of differentiation and concentration of technological operations, different technological equipment is provided for metal-cutting machines.

The developers are faced with the task of creating databases of tooling for CNC machine tools. This task is related to the problem of determining the trends in the development of the main aggregates of machine tools and tool systems, cutting and auxiliary tools. In the outline of the complex database "Tooling", the central element will be a section of 3D and parametric models of tools, taking into account perspective structures presented in patent funds.

Problems of analysis of development trends, identification of future promising structures are associated with the development of forecasts for design and technological facilities. In the process of prognostic analysis, as a rule, a number of constituent stages that are invariant to the specifics of the objects and systems under reviewing are considered. The main stages of the forecast study are the stages associated with the choice of the object and prediction method, generation of prediction data and verification of the obtained estimates. 


\section{Literature review}

Research in the field of forecasting can be systematized in three main classes, each of which uses a certain type of data: statistical series, expert statements and patent funds.

On the basis of statistical data, predictions of the effectiveness of machine tools with software control and their parametric reliability have been constructed [1-3]. The work [4] is devoted to revealing the level of the stress-strain state of the spindle assemblies and, as a consequence, the evaluation of wear and durability of metal cutting tools. Optimization of the cutting process and selection of progressive modes for processing parts from various materials is presented in [5].

In such forecasts extrapolation methods are widely used, taking into account the available statistics.

Analytical models are also widely used in prediction practice. Thus, in [6] an analytical model of wear of the front surface of turning cutters was proposed. As a research apparatus, a statistical method was used to investigate the response of the sensor signal and the method of neutron networks in the process of tool wear. On the basis of experimental data, the optimization procedure for the turning process is implemented. The study was limited to the specific material of the cutting part, therefore when the tool is changed, the obtained results may not correspond to the patterns of wear. Work [7] is devoted to predicting the wear degree with the help of a relatively new method of Smoothed Particle Hydrodynamics (SPH). This method takes into account the mechanism of elastoplastic deformation in the cutting zone, when the elementary volume of the cut layer is under the action of uniformly distributed hydrostatic pressure. The advantage of this method is a more adequate evaluation of the wear process, and hence the accuracy of the obtained predictive results. At the same time, the time required for conducting the experiments exceeds the experimental time on the basis of the finite element method. An analytic method is presented in [8], which allows predicting the wear of various forms of wear of a carbide tool for orthogonal cutting during turning. On the basis of the energy method, an equation is obtained that relates the wear characteristics with the data on the force values in the shaping of the chips. The authors carried out a computer simulation of the wear development process using the characteristic equation and the predicted stresses and temperatures on the wear surfaces. It is shown that the predicted rates of wear and tool life are in good agreement with the experimental results.

An increasing number of predictions and prospective projects are based on patent information. For example, in [9] new machining schemes and corresponding machine drive designs are introduced, based on the idea of approaching the motor to the machine forming units. Such promising solutions are presented as author's certificates in the sections of International Patent Classification (IPS) B23 of the Patents Fund. On the basis of technical innovations, a prospective design of a spindle unit of precision equipment is proposed [10]. In particular, the aerostatic support from composites and the new technology of manufacturing the bushing of a support by a casting method are considered. A new design of a non-contact magnetic coupling is presented in [10], which reduces the level of vibration of the spindle.

The presence of a large number of promising solutions, presented in various patent funds, gives impetus to a wide use of engineering prediction methods [11, 12].

\section{Materials and methods}

1. Selection of the prediction object (PO). At this stage, there is: refinement of the prediction object; its structure, functioning and development is analyzed; collection and systematization of initial information; the prediction object is synthesized as a set of essential characteristics that uniquely distinguish it on the set of similar ones. At this stage, the Tree of objects (TO) is effective, the rules for constructing it are given in $[13,14]$. The difference between the predictive review consists in "linking" it to the main development trends in the given subject area. Identification of the main development trends is carried out by analyzing the state and ways of improving the objects of the class under consideration - tooling of CNC machines with drilling, milling and boring type. Let's form "Tooling" TO (Fig. 1). Here let's note that such a tree is a "springboard" for constructing identical graph-trees of design and technological realizations. This is done by matching each goal 
(starting from the K-th level of the hierarchy) to the set of existing design and technological objects and their parts that implement the desired direction of improvement (goal realization).

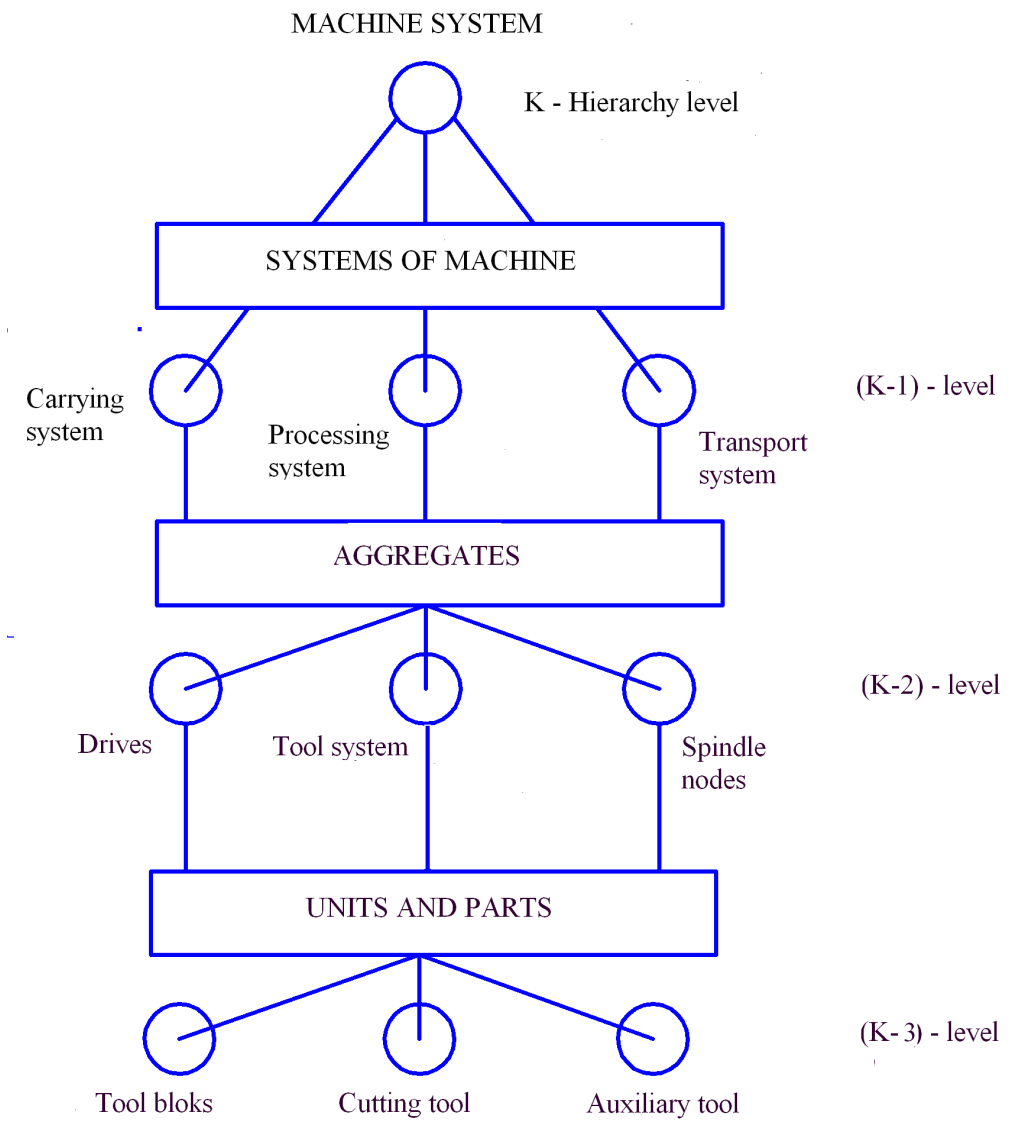

Fig. 1. Fragment of the Tree of objectives "Machining tools"

2. Choice of the prediction method (PM). The analysis of the trends in the development of machine-building objects is carried out using various methods - from unsystematized procedures for interviewing specialists in this field to the application of complex automated systems [15]. The presence of a large number of different methods of forecasting makes it necessary to build PM classifiers that have found application and are potentially applicable in the subject domain. A number of classifiers used in the PM technology are known [16], systematizing PM, relating to different classes. For each subject area, its modifications of the generalized classifier of the PM are needed.

For the analysis of trends in the development of machine-tool objects, a specialized compact PM classifier has been constructed [14], which includes three main classes of PM: statistical $\left(\mathrm{M}_{\mathrm{st}}\right)$, expert $\left(\mathrm{M}_{\mathrm{ex}}\right)$ and patent $\left(\mathrm{M}_{\mathrm{p}}\right)$. Each class includes a set of singular prediction methods (the lower level of the classifier). The complexity of forming a classifier at intermediate levels of the hierarchy is associated with the often encountered choice situations: the lack of clear trends in the development of the prediction object (PO); insufficient source information, etc. At the same time, the same construction procedure reflects the links between PO and PM, that is, the need to take into account the principle of parallel construction $[17,18]$. In this case, simultaneously with the construction of the PM sets in the classifier, the complex of essential PO characteristics is constructed and analyzed. However, here, the question arises: from what positions (the criterion of choice) to analyze and generate representations about the object of forecasting.

It is proposed to use as a selection criteria for PM:

$\mathrm{G}_{1}$ - prediction purpose;

$\mathrm{G}_{2}$ - specificity of the prediction object;

$\mathrm{G}_{3}$ - information supply. 
Evaluation scales [14] of selection criteria have been developed, on the basis of which it is possible to evaluate their effectiveness for the PM selection process. Taking into account the problems of the absence of a common scale and the use of dissimilar (hard [19]) scales for the criteria $\mathrm{G}_{1}$ and $\mathrm{G}_{2}$, the criterion $\mathrm{G}_{3}$ (PO information supply) has been adopted as the main criterion. The latter is the most efficient and quantitatively measurable at the stage of choosing a class of methods.

The selection of the main criterion $\mathrm{G}_{3}$ predetermines the process of encoding the PO with the information code: $\mathrm{I}_{\mathrm{c}}=<\mathrm{C}_{\mathrm{m}} ; \mathrm{B}$; $\mathrm{P}>$, including a three-element set of classes of information sources - static data $\left(\mathrm{C}_{\mathrm{m}}\right)$, expert estimates $\left(\mathrm{B}_{\mathrm{e}}\right)$, patent data $(\mathrm{P})$. Each element of the set includes types of initial information for identification of which the corresponding algorithms have been developed [14], according to which each class is assigned the following values:

$-\mathrm{C}_{\mathrm{m}}:=\mathrm{C}_{\mathrm{m} 1} \vee \mathrm{C}_{\mathrm{m} 2} \vee \mathrm{C}_{\mathrm{m} 3}-$ depending on the number of terms (n) of the time series $\mathrm{y}_{\mathrm{t}}$, as well as on the ratio of the flashback time $\left(\mathrm{t}_{\mathrm{f}}\right)$ and the lead time $\left(\mathrm{t}_{\mathrm{l}}\right)$;

$-\mathrm{B}_{\mathrm{e}}:=\mathrm{B}_{\mathrm{e} 1} \vee \mathrm{B}_{\mathrm{e} 2}-$ depending on the number of experts who took part in the examination; patents $\left(\mathrm{n}_{\mathrm{p}}\right)$.

$-\mathrm{P}:=\mathrm{P}_{1} \vee \mathrm{P}_{2} \vee \mathrm{P}_{3}-$ depending on the type of patent information $\left(\mathrm{P}_{\mathrm{i}}\right)$ and number of considered

The estimated scale of criterion $\mathrm{G}_{3}$ is presented in Table 1

Table 1

Evaluation scale of the "Information security" criterion

\begin{tabular}{cccc}
\hline & Value I & Symbol & Scale \\
\hline $\mathrm{B}_{91}$ & $\mathrm{I}_{1}$ & $\mathrm{I}_{2}$ & Nominal scale \\
Information security (I) & $\mathrm{P}_{1}$ & $\mathrm{I}_{3}$ & \\
& $\mathrm{P}_{2}$ & $\mathrm{I}_{4}$ & $\mathrm{I}_{5}$ \\
$\mathrm{C}_{\mathrm{m} 1}$ & $\mathrm{I}_{6}$ & \\
$\mathrm{C}_{\mathrm{m} 2}$ & $\mathrm{I}_{7}$ \\
$\mathrm{~B}_{\mathrm{e} 2}$ & $\mathrm{I}_{8}$
\end{tabular}

PO information codes can be put in correspondence information codes $P M-\left\{M_{s} ; M_{e x} ; M_{p}\right\}$.

To form a model of patent methods $\mathrm{M}_{\mathrm{p}}$ (Table 2), let's distinguish two main features of $\mathrm{K}_{\mathrm{p}}^{\mathrm{i}}$ and form the code of the class of patent prediction methods: $\mathrm{K}_{\mathrm{p}}=<\mathrm{K}_{\mathrm{p}}^{1}, \mathrm{~K}_{\mathrm{p}}^{2}>$

Table 2

A set of characteristics that affects the choice of methods of patent prediction

\begin{tabular}{cccc}
\hline Symbol & Characteristics & $\begin{array}{c}\text { Name of the characteristic } \\
\text { value }\end{array}$ & Conditional designation \\
\hline $\mathrm{K}_{\mathrm{p}}^{1}$ & Number of patent data & Young Patent Fund & $\mathrm{K}_{\mathrm{p}}^{11}$ \\
& & Representative Patent Fund & $\mathrm{K}_{\mathrm{p}}^{12}$ \\
$\mathrm{~K}_{\mathrm{p}}^{2}$ & Nature of patent data & Patents & $\mathrm{K}_{\mathrm{p}}^{21}$ \\
& & Technical Strategies & $\mathrm{K}_{\mathrm{p}}^{22}$
\end{tabular}

\section{Experiments}

To assess the prospects for the design of machining tools, the IPC patent information in groups B23, B27, C04, C21 is considered as the initial information, which is identified by code $\mathrm{P}_{3}$ 
$\left(\mathrm{K}_{\mathrm{p}}^{12}\right)$. The second source of information is the statement of the expert on the problem of improving the machining tools, which can be identified by the code $\mathrm{B}_{\mathrm{el}}\left(\mathrm{K}_{\mathrm{e}}^{51}\right)$.

The method class is selected from the logical relationship:

$$
\mathrm{P}_{3} \wedge \mathrm{B}_{\mathrm{yl}}\left(\mathrm{K}_{\mathrm{p}}^{12} \wedge \mathrm{K}_{\mathrm{e}}^{51}\right) \rightarrow \mathrm{M}_{\text {i.p. }}
$$

For patent information $\mathrm{K}_{\mathrm{p}}^{21}$ from the representative patent fund $\mathrm{K}_{\mathrm{p}}^{12}$ a well-proven method of engineering forecasting [11, 12] is applied, the main instrument of which is the general definition table (GDT). Table 3 presents a number of promising patent solutions related to components of tooling. The estimation of the prospects (engineering-technical significance $\mathrm{T}$ is carried out on the basis of the characteristic properties (characteristics $i_{j}$, including the material of the cutting part of the tool $\left(i_{1}\right)$, the geometry of the cutting wedge $\left(i_{2}\right)$, the linking of the tool and the machine $\left(i_{3}\right)$, the construction of the fastening of the cutting insert $\left(i_{4}\right)$; chip breaking device $\left(i_{5}\right)$.

Table 3

GDT "Components of machining tools"

\begin{tabular}{|c|c|c|c|c|c|c|c|c|}
\hline \multirow{2}{*}{$\begin{array}{c}\text { Country, class, patent } \\
\text { number }\end{array}$} & \multirow{2}{*}{ The name of the patent } & \multicolumn{5}{|c|}{ Basic evaluation } & \multirow{2}{*}{$\mathbf{T}$} & \multirow{2}{*}{ Category } \\
\hline & & $\mathbf{i}_{1}$ & $\mathbf{i}_{2}$ & $\mathbf{i}_{3}$ & $\mathbf{i}_{4}$ & $\mathbf{i}_{5}$ & & \\
\hline SU, B23 B27/00, No. 1349878 & Cutting tool & 5 & 5 & 4 & 5 & 1 & 0,88 & Very perspective \\
\hline US, B23 C5/26 No. 4971491 & Tool holder & 4 & 5 & 4 & 2 & 3 & 0,78 & Perspective \\
\hline SU, B23 C5/28, No. 1692768 & Interlocking side mill & 5 & 5 & 3 & 3 & 4 & 0,84 & Very perspective \\
\hline JP, B23 C5/10, No. 14564 & End milling cutter & 3 & 4 & 3 & 5 & 3 & 0,71 & Perspective \\
\hline SU, B23 C5/26, No. 1685630 & Device for connecting the tool module & 4 & 5 & 1 & 5 & 4 & 0,76 & Perspective \\
\hline SU, B23 C5/26, No. 1685631 & $\begin{array}{l}\text { Tool clamping device in the machine } \\
\text { spindle }\end{array}$ & 5 & 5 & 4 & 5 & 4 & 0,94 & Very perspective \\
\hline SU, B23 C5/26, No. 4-948309 & Clamping device for holder & 4 & 4 & 5 & 4 & 3 & 0,82 & Very perspective \\
\hline
\end{tabular}

In the practice of designing machining tools, it is important to build databases of design solutions. Within this database, the sections of 3D models created in the computer-aided design KOMPAS-3D system are singled out [20-22]. Fig. 2 presents a number of promising designs, with which the machines of a drilling, milling and boring group are equipped. The choice of specific models is made taking into account the GDT estimates (Table 3).

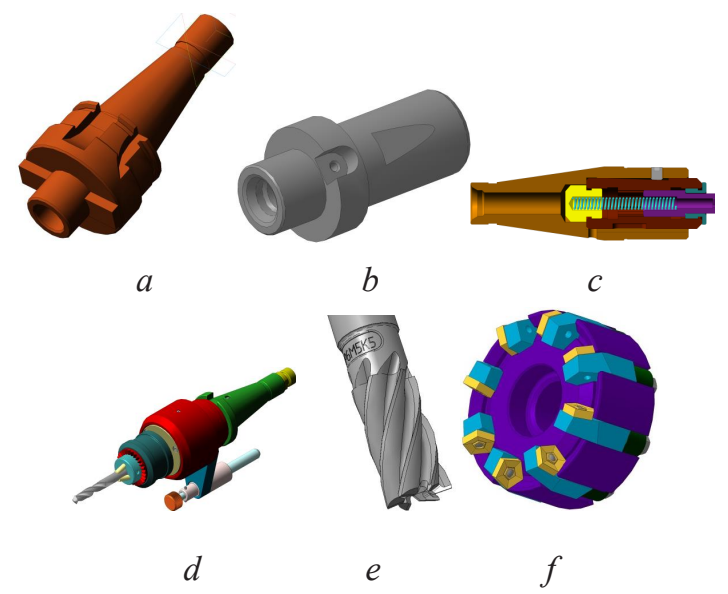

Fig. 2. 3D models of machining tools' components: $a$ - tool holder; $b$-transition sleeve; $c$ - tool clamping device; $d$ - high-speed head; $e$ - end milling cutter; $f$-interlocking side mill 


\section{Results}

Models and procedures for the rational choice of tooling structures using methods of engineering forecasting based on analysis of development trends and patent funds in the area under consideration have been developed.

A formalized procedure for constructing a tree of objectives is designed to analyze the structure and minimize the composition of instrumentation at the stage of selecting the prediction object.

Here let's note that such tree is a "springboard" for constructing identical graph-trees of design and technological.

An approach is proposed for solving the problem of choosing the forecasting method, which is not limited to the use of expert estimates and the coding of data on the specifics of the object and the forecasting method, but is solved by singling out the main criterion "Information supply". In turn, this choice predetermines the process of encoding the prediction object with an information code including a three-element set of classes of information sources - static data, expert estimates and patent data. In this respect, an approach based on the parallel construction of a set of alternative PM, formalized models of objects and methods of forecasting, a system of preferences and decisive rules for selecting a class of methods and singular statistical and patent prediction methods is promising.

The efficiency of using engineering forecasting methods is shown, and a general definition table for evaluating and selecting promising tooling structures for program-controlled machine tools and machining centers is generated.

\section{Conclusions}

As a result of the conducted researches the approach to designing of a various nomenclature of tool equipment of program-controlled metal-cutting machine tools is offered. The main task facing the researchers is creation of a competitive design that will enter the market after a certain time interval in the future. And this means that without taking into account the current development trends, without introduction of avant-garde patent decisions into the project, it will be problematic to perform such task. The authors propose a procedure for targeted search and selection of the most promising constructive elements that are built into the process of designing tooling. To do this, methods such as tree of objectives and patent prediction are used. At the same time, the proposed approach slightly lengthens the design time, changes the nature of the interaction of project teams within the design organization.

This kind of forecasting research can be useful for large industrial design institutes of machine-tool profile, where significant volumes of information are concentrated on the development of this industry, analysis of market needs, international cooperation in this field.

This work is a continuation of the research carried out by the authors in the field of development of machine tool constructions, and takes into account the specificity of various tooling. Further developments will be aimed at creating structured databases of tooling with the ability to embed patent information in the design process outline.

\section{References}

[1] Push, A. V. (1981). Prognozirovanie parametricheskoy nadezhnosti shpindelnyih uzlov s pomoschyu EVM [Prediction of parametric reliability of spindle nodes with the help of a computer]. Izvestiya vuzov, 10, 107-112.

[2] Push, A. V. (1985). Prognozirovanie parametricheskoy nadezhnosti shpindelnyih uzlov s uchetom teplovyih protsessov [Prediction of parametric reliability of spindle nodes with allowance for thermal processes]. Izvestiya vuzov, 3, 142-146.

[3] Push, A. V. (1985). Prognozirovanie teplovyih smescheniy shpindelnyih uzlov [Prediction of thermal displacements of spindle nodes]. Stanki i instrument, 5, 15-19.

[4] Poduraev, V. N. (1993). Prognozirovanie stoykosti rezhuschego instrumenta [Prediction of the durability of the cutting tool]. Vestnik mashinostroeniya, 1, 30-36. 
[5] Pryalin, M. A. (1991). Prognozirovanie rezhimov rezaniya nemetallicheskih materialov metodom statisticheskoy otsenki [Prediction of cutting modes of nonmetallic materials by the method of statistical estimation]. Rezanie i instrument, 46, 124-125.

[6] Attanasio, A., Ceretti, E., Giardini, C. (2013). Analytical Models for Tool Wear Prediction During AISI 1045 Turning Operations. Procedia CIRP, 8, 218-223. doi: https://doi.org/10.1016/j.procir.2013.06.092

[7] Stenberg, N., Delić, A., Björk, T. (2017). Using the SPH Method to Easier Predict Wear in Machining. Procedia CIRP, 58, 317-322. doi: https://doi.org/10.1016/j.procir.2017.03.234

[8] Usui, E., Shirakashi, T., Kitagawa, T. (1984). Analytical prediction of cutting tool wear. Wear, 100 (1-3), 129-151. doi: https://doi.org/10.1016/0043-1648(84)90010-3

[9] Pestunov, V. M. (1994) Novyie shemyi obrabotki i struktura privoda stankov [New processing schemes and the structure of drive machines]. STIN, 2, 35-39.

[10] Gao, V. (1993). Novaya sistema shpindelya dlya pretsezionnogo stanka [New spindle system for a precision machine]. Razvitie sovremennogo metalloobrabatyivayuschego oborudovaniya v Rossii i Kitae. Moscow: ENIMS, 135-139.

[11] Gmoshinskiy, V. G. (1982). Inzhenernoe prognozirovanie [Engineering Forecasting]. Moscow: Energoizdat, 208.

[12] Gmoshinskiy, V. G. (1988). Inzhenernoe prognozirovanie tehnologii stroitelstva [Engineering forecasting of construction technology]. Moscow: Stroyizdat, 295.

[13] Bestuzhev-Lada, I. V. (1982). Rabochaya kniga po prognozirovaniyu [Working book on forecasting]. Moscow: Myisl, 430.

[14] Krol, O. S., Sokolov, V. I. (2017). Metody i procedury inzhenernogo prognozirovaniya v stankostroenii [Methods and procedures of engineering forecasting in machine tool building]. Lugansk: VNU, 116.

[15] Zhuk, K. D., Krol, O. S., Timchenko, A. A. (1984). Prognosticheskiy analiz ob’ektov novoy tehniki i tehnologii v zadachah sistemnogo proektirovaniya [Predictive analysis of objects of new technology and technology in problems of system design]. Kyiv: Institut Kibernetiki AN USSR, 27.

[16] Sarkisyan, S. A., Golovanov, L. V. (1975). Prognozirovanie razvitiya bolshih tehnicheskih sistem [Forecasting the development of large technical systems]. Moscow: Statistika, 192.

[17] Krol, O. S., Sokolov, V. I. (2017). Metody i procedury racional'nogo vybora v stankostroenii [Methods and procedures of rational choice in machine tool construction]. Lugansk: VNU, 112.

[18] Krol, O., Tsankov, P., Sokolov, V. (2018). Rational choice of two-support spindles for machining centers with lubrication system. EUREKA: Physics and engineering, 3, 52-58. doi: https:// doi.org/10.21303/2461-4262.2018.00648

[19] Kini, R. L., Rayfa, H. (1981). Prinyatie resheniy pri mnogih kriteriyah predpochteniya i zamescheniya [Decision-making under many preference and substitution criteria]. Moscow: Radio i svyaz, 560.

[20] Krol, O., Zhuravlev, V. (2014). Modeling of spindle for turret of the specialized tool type SF16MF3. TEKA Commision of Motorization and Energetic in Agriculture, 13 (4), 141-147.

[21] Krol, O. S., Krol, A. A., Burlakov, E. I. (2013). Tverdotelnoe modelirovanie i issledovanie shpindelnogo uzla obrabatyivayuschego tsentra [Solid modeling and investigation of the spindle node of the machining center]. Visnik Natsionalnogo tehnichnogo universitetu «KhPI», 16 (989), 14-18.

[22] Sokolov, V., Krol, O. (2017). Installations Criterion of Deceleration Device in Volumetric Hydraulic Drive. Procedia Engineering, 206, 936-943. doi: https://doi.org/10.1016/j.proeng.2017.10.575 